\title{
Apa dan Mengapa Ilmu Informasi?
}

\author{
Ida Fajar Priyanto \\ Perpustakaan Universitas Gadjah Mada \\ Bulaksumur, Kotak Pos 16, Yogyakarta \\ Email: idafajarpriyanto@yahoo.com
}

\begin{abstract}
Abstrak - Ilmu Informasi adalah ilmu interdisipliner yang membahas tentang interpretasi informasi dan berbagai hal terkait dengan proses kognitif, konteks dan fenomena informasi. Ilmu informasi masih merupakan ilmu baru yang berdiri sejak tahun 1950an dan saat ini masih dalam masa berkembang. Pada awalnya ilmu informasi sangat erat hubungannya dengan sistem, namun kini beralih ke faktor manusia dalam informasi, termasuk perilaku informasi dan ergonomi.
\end{abstract}

Kata kunci: Ilmu, Ilmu Informasi, Ilmu Perpustakaan

Abstract - Information science is an interdisciplinary science that deals with the interpretation of information and relates to cognitive process, context and the phenomena of information. Information science has developed since 1950s and is still growing. It formerly dealt with system, but currently it turns to human factor of information, including information behavior and ergonomics.

Keyword: Information Science, Information Science

\section{PENDAHULUAN}

Di Indonesia, Jurusan Ilmu Perpustakaan seringkali diberikan tambahan nama dengan informasi, sehingga kemudian menjadi Ilmu Perpustakaan dan Informasi atau Ilmu Informasi dan Perpustakaan. Kemudian beberapa pengelola Ilmu Perpustakaan menambahkan Ilmu Informasi sebagai bagian dari Ilmu Perpustakaan. Ini menjadikan Ilmu Informasi sebagai bagian dari Ilmu Perpustakaan. Sementara di DIKTI hanya ada nomenklatur Ilmu Perpustakaan dan tidak ada Ilmu Informasi karena memang Ilmu Informasi belum berkembang sama sekali di Indonesia. Belum dapat dipastikan kapan akan ada jurusan atau program studi Ilmu Informasi. Kalangan di luar Ilmu
Perpustakaan dan Informasi juga memandang informasi sebagai bagian dari Ilmu Perpustakaan, bahkan Jurusan Ilmu Perpustakaan dan Informasi seringkali dilihat oleh kalangan di luar Ilmu Perpustakaan sebagai ilmu yang mengelola perpustakaan. Di sisi lain lagi, kebanyakan pengajar di dalam Ilmu Perpustakaan atau Ilmu Perpustakaan dan Informasi pada umumnya adalah lulusan Ilmu Perpustakaan baik dari dalam atau dari luar negeri. Hal inilah yang kemudian membuat pandangan tentang Ilmu Informasi semakin sempit.

Tidak kalah menarik adalah sebagian kalangan pustakawan sendiri merasa kurang percaya diri dengan sebutan pustakawan untuk profesinya dan perpustakaan untuk tempat bekerjanya; sementara kalau disebut sebagai ahli informasi jelas belum sesuai karena latar belakangnya adalah Ilmu Perpustakaan.

\section{Apakah Ilmu informasi?}

Ilmu Informasi atau dalam bahasa Inggris disebut sebagai Information science adalah ilmu interdisipliner baru yang membahas interpretasi informasi. Ilmu Informasi dapat dikatakan memiliki tiga aspek penting, yaitu fenomena dasar informasi, proses kognitif, dan konteks informasi atau informasi dalam konteks. Ilmu Informasi dipandang sebagai suatu ilmu interdisipliner karena kedekatannya dengan kajian dan perkembangan area keilmuannya. Informasi merupakan isu penting dalam sistem manajemen informasi, informasi produk dalam dunia pemasaran, perpustakaan, matematika, sosiologi, komunikasi dan komputer. Itulah mengapa Ilmu Informasi 
selalu dipandang memiliki hubungan erat dengan ilmu-ilmu lain dan kajian kolaboratif bidang informasi akan mendukung Ilmu Informasi sebagai ilmu interdisipliner. Kajian penelitian Ilmu Informasi sangat luas dari aspek matematika sampai aspek kognitif, misalnya pengukuran kajian tentang besarnya informasi dalam web, perilaku informasi, kebutuhan informasi, penelusuran informasi, pemanfaatan informasi, kualitas informasi, dan nilai informasi. Belkin (1978) bahkan mengidentifikasi adanya beberapa kaitan dalam Ilmu Informasi, yaitu informasi yang diharapkan (desired information), (2) informasi dalam system kognitif atau manusia, (3) hubungan antara informasi, pembuat informasi dan pengguna informasi, dan (4) efektivitas informasi.

Menurut Wersig dan Neveling (1975), Ilmu Informasi berkembang sejak tahun 1950an dan pada awalnya bukanlah dari paduan antara satu ilmu dengan ilmu lain atau paduan dari minat bidang ilmu, namun berkembang dari apa yang pada awalnya disebut dokumentasi atau temu kembali informasi, terutama dengan adanya pemanfaatan teknologi yang kemudian membawa Ilmu Informasi pada kuantifikasi informasi. Munculnya kuantifikasi informasi juga diawali dengan Memex-nya Bush (1999) beberapa tahun sebelumnya.

Meadows (1990) juga mengatakan bahwa Ilmu Informasi modern sekarang ini berawal dari Ilmu Informasi pada tahun 1950an. Karya ilmiah Shannon yang terkait dengan sisi kuantifikasi informasi menarik banyak peneliti. Kajian kuantifikasi informasi berkembang ke kajian informasi terekam dan kemudian muncullah apa yang disebut dengan bibliometrik. Bradford and Lotka telah melakukan kajian terhadap kajian matematika informasi dalam bibliometrik. Bahkan dalam era Google sekarang ini, bibliometrik telah berkembang menjadi webometrik yang dipicu oleh munculnya internet.

Pada masa-masa awal, pada umumnya kajian informasi selalu berbasis sistem (the systemcentered studies) dan mengabaikan peran manusia dalam informasi. Semua pengukuran informasi hanya terkait dengan informasinya sendiri, tanpa memandang segi manusia yang membuat informasi maupun yang menerima informasi. Pada tahun 1970an dan 1980an, era baru kajian Ilmu Informasi muncul, terutama dalam kaitannya dengan munculnya penggunaan komputer. Para pakar Ilmu Informasi kemudian mulai tertarik dengan unsur manusia dalam informasi maupun teknologinya. Penggunaan komputer untuk menangani informasi kemudian mengarah pada sisi manusianya. Interaksi komputer dan manusia maupun interaksi manusia dengan komputer kemudian berkembang menjadi kajian lebih detil dalam interaksi manusia dan komputer (human-computer interaction atau HCI) dan sampai saaat ini kajian tentang hal ini masih terus berkembang. Meadows (1990) juga memandang fenomena ini sebagai hasil kajian dari luar Ilmu Informasi. Sebagai contoh, Ilmu Psikologi, Ilmu Kesehatan dan perangkat keras komputer yang kemudian menghasilkan ergonomik dalam kajian Ilmu Informasi. Perkembangan ilmu kognitif telah meningkatkan keterkaitan antara unsur manusia dan informasi dan karenanya Ilmu Informasi banyak menghasilkan kajian-kajian dalam perilaku informasi, kebutuhan informasi dan pemanfaatan informasi.

Perlu dipertimbangkan bahwa isu terkait dengan komputer dan kajian manusia dalam Ilmu Informasi tidak harus dipandang sebagai isu yang besar dan kritis, melainkan dilihat sebagai dua bidang yang berbeda, tetapi keduanya memberikan pemahaman yang lebih mendalam tentang peran manusia dan komputer atau teknologi informasi secara umum.

Sebagai ilmu interdisipliner, Ilmu Informasi sangat erat kaitannya dengan (dan semakin meningkat) sejumlah ilmu lainnya. Namun demikian, tidak semua ilmu menjadi semakin dekat dengan Ilmu Informasi, melainkan ada yang semakin mendekat, tetapi ada yang semakin menjauhi Ilmu Informasi. Dan interrelasi beberapa ilmu yang berkecimpung dalam informasi seringkali membingungkan banyak orang dalam mendefinisikan Ilmu Informasi meskipun 
sebetulnya kebingungan itu sendiri dapat dilacak alasannya.

Ilmu Informasi dan Ilmu Perpustakaan misalnya, adalah dua bidang yang berbeda tetapi terkait. Meskipun keduanya terkait erat dengan informasi, baik Ilmu Perpustakaan maupun Ilmu Informasi memiliki dasar teori dan metodologi yang berbeda, begitu juga dengan solusi atas masalah informasi yang harus ditangani dalam Ilmu Informasi maupun Ilmu Perpustakaan. Ilmu Informasi sangat "concern" dengan temu kembali informasi, sementara Ilmu Perpustakaan lebih mengarah pada automasi karena ilmu ini mengarah pada praktikalitas. Ilmu Informasi juga sangat dekat dengan Ilmu Komputer. Namun keduanya juga berbeda. Ilmu Komputer terkait erat dengan algoritma sedang Ilmu Informasi terkait dengan informasi dan pemanfaatannya.

Informasi sendiri dikaji dalam berbagai bidang atau disiplin ilmu.

Tidak kalah penting adalah apa yang disampaikan oleh Trudi Bellardo Hahn, presiden ASIS \& T tahun 2002-2003 (White 2009). Beliau mengatakan bahwa Ilmu Informasi telah melakukan banyak hal yang dapat diringkas menjadi 5 kategori berikut:

1. Kajian tentang ledakan informasi yang kemudian menghasilkan bibliometrik, kajian tentang literatur publikasi dan pemanfaatannya serta hal-hal yang terkait lainnya seperti sitasi, pengaruh, pola sitasi, produktivitas dan komunikasi ilmiah, dan sebagainya.

2. Ilmu Informasi memulai system indexing yang berbeda dengan katalogisasi perpustakaan, seperti indexing dan pengabstrakan otomatis, KWIC and KWOC indexing, indeks sitasi, indeks kata kunci dan pascakoordinasi, analisis teks dan penelusuran dengan bahasa alamiah, pengembangan thesauri atau controlled vocabularies untuk berbagai disiplin ilmu dengan konsentrasi atau minatnya

3. Ilmu Informasi menerapkan komputasi untuk memanipulasi dokumen dan perekaman dokumen dalam sistem penyimpanan dan temu kembali informasi yang dimulai pada tahun 1950an dan berkembang setelah tahun 1960an. Termasuk didalamnya adalah aplikasi formal logic (operator Boolean) untuk penelusuran database.

4. Ilmu Informasi mempelajari perilaku pencarian informasi (information seeking), kebutuhan informasi (information needs) dan berkembang ke relevansi, evaluasi pemanfaatan, keakuratan informasi dan sebagainya.

5. Kontribusi Ilmu Informasi yang terkait dengan pemerintah dan industri adalah kebijakan informasi dalam hubungannya dengan privasi, keamanan, pengaturan dan diseminasi dan akses informasi, HAKI. Juga pengembangan standar pemrosesan dan komunikasi informasi, monitoring infrastruktur informasi (SDM. teknologi, perangkat dan keuangan) dalam rangka pengelolaan dan layanan informasi.

Menurut Zhao, Tang, Darlington, Austin, dan Culley (2008) informasi dikaji oleh berbagai bidang, seperti manajemen, analisis resiko jaringan, pembuatan keputusan, akuntansi dan keuangan, serta bidang ilmu perpustakaan dan informasi dan teknik. Fetham (1968) pernah mengkaji tentang nilai informasi terkait dengan bidang akuntansi. Kajiannya menunjukkan bahwa relevansi, waktu dan keakuratan informasi sangat penting dalam bidang akuntansi. Zhao et al. (2008) juga pernah mengkaji informasi dalam organisasi teknik, sementara itu Cernohorsky and Voracek (2012) mengkaji informasi dalam pemasaran layanan kesehatan.

Matthews (2001) melakukan kajian terkait dengan informasi dalam kaitannya dengan katalog perpustakaan. Penelitian ini memberikan gambaran bagi pustakawan untuk mengkaji ulang berapa besar biaya yang dikeluarkan untuk membuat katalog perpustakaan dan seberapa banyak pemustaka memanfaatkan katalog perpustakaan. Koops (2004) meneliti tentang nilai informasi binatang. Dalam kajian tersebut ditemukan bahwa 
binatang juga selalu memiliki pilihan untuk mengabaikan informasi yang tidak memiliki nilai bagi binatang tersebut. Seekor kucing yang melihat tidak ada nilai dari panggilan atau tawaran pemilik akan membiarkan pemilik memanggil manggil kucing tersebut.

Masih banyak kajian-kajian yang terkait dengan informasi yang dilakukan dari berbagai bidang ilmu, tetapi pada intinya, Ilmu Informasi, sebagai bidang baru yang interdisipliner, akan terus berkembang. Sudah saatnya Indonesia mempertimbangkan pentingnya Ilmu Informasi diajarkan di Indonesia secara lebih mendalam, bukan sekedar menjadi bagian dari Ilmu Perpustakaan. Selain itu, banyak pakar yang menggeluti bidang Ilmu Informasi ini, seperti misalnya Tefko Saracevic, Michael Buckland, Colin Burke, Bates, A. J. Meadowss, Christine Borgman, dan T. D. Wilson.

\section{PENUTUP}

Dapat dikatakan bahwa Ilmu Informasi adalah ilmu interdisipliner yang terkait dengan informasi dari berbagia sudut pandang dan pendekatan. Ilmu Informasi akan terus berkembang sebagai ilmu yang akan berperan penting dalam kajian ilmiah. Di Indonesia Ilmu Informasi sering dianggap sama dengan Ilmu Perpustakaan, padahal Ilmu Informasi jauh berbeda dengan Ilmu Perpustakaan. Bahkan boleh dikatan Ilmu Perpustakaan bisa menjadi salah satu minat dari Ilmu Informasi atau paduan antara Ilmu Informasi dan Perpustakaan.

Beberapa program studi Ilmu Perpustakaan di Indonesia mulai menggunakan nama Ilmu Informasi dan Perpustakaan atau Ilmu Perpustakaan dan Informasi, namun bobot keilmuan Ilmu Informasi masih tidak seimbang dan bahkan didominasi oleh Ilmu Perpustakaan. Di Indonesia, informasi dianggap sebagai bagian dari Ilmu Perpustakaan dan ini adalah pandangan yang harus dirubah. Para pustakawan harus melihat Ilmu Informasi dari kacamata yang lebih luas lagi. Kurikulum Ilmu Perpustakaan dan Informasi dapat dipadukan dengan menambahkan kajian-kajian dalam bidang informasi sehingga bobot keilmuan
Ilmu Informasi akan berimbang dalam Ilmu Perpustakaan dan Informasi.

Selain itu di masa mendatang kita berharap DIKTI dapat memasukkan nomenklatur informasi sebagai salah satu program studi atau jurusan. Juga perlu dipertimbangkan adanya Jurusan Ilmu Informasi yang di dalamnya terdapat program studi atau minat Ilmu Perpustakaan, Kearsipan, dan Ilmu Informasi itu sendiri seperti halnya di berbagai jurusan atau fakultas Ilmu Informasi di negaranegara lain.

\section{DAFTAR PUSTAKA}

Belkin, Nicholas J. 1978. "Progress in Documentation: Information Concepts for Information Science". Journal of Documentation 34(1): 55-85.

Bush, Vannevar. 1999. "As We May Think". Library Computing 18(3): 180-188.

Cernohorsky, Petr, and Jan Voracek. 2012. "Value of Information in Health Services Market". Measuring Business Excellence Journal 16(4): 42-53.

Feltham, Gerald A. 1968. "The Value of Information". The Accounting Review 43(4): 684-696.

Koops, Marten A. 2004. "Reliability and the Value of Information". Animal Behavior 67: 103111. Diakses 8 Februari 2003. doi: 10.1016/j.anbehav.

Matthews, Joseph R. 2001. "The Value of Information: The Case of the Library Catalog". Technical Services Quarterly 19(2): 1-16.

Meadows, A. Jack. 1990. "Theory in Information Science". Journal of Information Science 16: 59-63.

Wersig, Gemot \& Ulrich Neveling. 1975. "The Phenomena of Interest to Information Science". The Information Scientist 9(4): 127-140.

White, Howard. D. 2009. "Bibliometric Overview of Information Science". Encyclopedia of Library and Library Sciences $3^{\text {rd }}$ Ed. 1:1, 534-545.

Diakses dari 
http://www.informaworld.com/smpp/titlecontent $=\mathrm{t} 917508581$

Zhao, Yuyang, Llewellyn Tang, M. Darlington, Simon A. Austin, and S. Culley. 2008. "High value information in engineering organisations". International Journal of Information Mangement 28: 246-258. 